\title{
School Location and Factors Affecting Parents' Mode Choice to School
}

\author{
Na'asah Nasrudin, Sofia Alimudin, Habsah Hashim, \\ Marlyana Azyyati Marzukhi, Yusfida Ayu Abdullah \\ Centre of Studies for Town and Regional Planning, Faculty of Architecture, Planning and Surveying, \\ Universiti Teknologi MARA Puncak Alam Campus, 42300 Selangor, Malaysia \\ naasa717@uitm.edu.my, nurulsofiaalimuddin@gmail.com, habsah99@yahoo.com, marlyanaazyyati@gmail.com, yusfida@salam.uitm.edu.my \\ Tel: +60122023297
}

\begin{abstract}
This paper examines the influences of the built environment (distance between home and school) on the journey to school as a measure to promote active transportation to school. Data collected through a survey of 150 parents to represent Section 7 residents of Shah Alam, Selangor. This study shows that there is an insignificant relationship between school location and parents' transportation mode choice. The most popular mode of transport chosen by parents was their private car compared to walking and cycling even though the distance from home to school was less than 800 meters because of a safety factor.
\end{abstract}

Keywords: school travel; active transportation; school location; safety.

eISSN: 2398-4287C 2020. The Authors. Published for AMER ABRA cE-Bsby e-International Publishing House, Ltd., UK. This is an open access article under the CC BYNC-ND license (http://creativecommons.org/licenses/by-nc-nd/4.0/). Peer-review under responsibility of AMER (Association of Malaysian Environment-Behaviour Researchers), ABRA (Association of Behavioural Researchers on Asians) and cE-Bs (Centre for Environment-Behaviour Studies), Faculty of Architecture, Planning \& Surveying, Universiti Teknologi MARA, Malaysia. DOI: https://doi.org/10.21834/ebpj.v5iSI3.2579

\subsection{Introduction}

The number of children walking and cycling to school becomes even lesser than previous time in Malaysia. Most of the parents choose to send their children with motorised vehicles such as school buses or parents' vehicles, hence causes traffic congestion near the school. McMillan (2007) and Pooley et al. (2005) mentioned several factors that contribute to the choice of students' transport in urban areas. These include the distance between home and school, car ownership, the increasing number of working mothers, urban form, and complex family schedules. Survey results from households in Georgia USA in 2000 found that children aged 5 to 15 years, living within a mile from the school, driven by their parents (Bricker et al., 2002.). Based on the study from the Department for Transport in London, England, the number of primary school children walking to school decreased from $61 \%$ in 1992 to 1994 to $52 \%$ in 2002 to 2003. Meanwhile, travelling by car has increased from 30\% to 40\% (McMillan 2005).

Like other countries, school areas congested with vehicles is also a common scenario in the Malaysian urban areas. This usually occurs at peak times during the start and end of a school day. This scenario would constrain the success in realizing a sustainable transportation development system in Malaysia. Driving children to school can deprive them of an opportunity for daily physical activity while generating $20 \%$ to $30 \%$ of the morning traffic in some places (Safe Routes to School National Partnership \& Hubsmith, 2006, 2007).

eISSN: 2398-4287@ 2020. The Authors. Published for AMER ABRA cE-Bsby e-International Publishing House, Ltd., UK. This is an open access article under the CC BYNC-ND license (http://creativecommons.org/licenses/by-nc-nd/4.0/). Peer-review under responsibility of AMER (Association of Malaysian Environment-Behaviour Researchers), ABRA (Association of Behavioural Researchers on Asians) and cE-Bs (Centre for Environment-Behaviour Studies), Faculty of Architecture, Planning \& Surveying, Universiti Teknologi MARA, Malaysia. DOI: https://doi.org/10.21834/ebpj.v5iSI3.2579 
The decreased level of walking freedom among school children can be associated with parental fears of the dangers of ongoing traffic and kidnapping or harassment (Martin and Carlson (2005) and McMillan (2007). According to MIROS (2011), the fatal road injuries in Malaysia among children below 18 years old, had increased from $13.6 \%$ in 2007 to $15.5 \%$ in 2009. It is reported that $11.6 \%$ of children (1-18 years old) suffering from fatal road traffic injuries are pedestrians. The highest figure is expected to be among the age group 5-9 years old since the fact that children in that age group need adult's supervision while walking or crossing the road, as proven in a study conducted by the National Center for Safe Routes to School (PICB, 2007).

The New Urbanism theories hypothesize that making places where destinations are close, the route is interesting, and safety concerns minimized can promote walking and cycling. Encouraging active transportation to school is influenced by locational factors of the home and the school and past research confirmed that distance is the strongest predictors of walking and cycling to school. School policies that promote school choice and set guidelines for school facilities (including size and location) can have a big impact on the distance between home and school, and by association, will also influence the mode choice for travel to and from school. (Weigand L, 2008).

\subsection{Method}

Sekolah Rendah Kebangsaan Seksyen 7, Shah Alam was chosen as a case study because it is located in the urban area, which deals with high traffic volume daily. A total of 150 respondents were selected for this survey using the convenience sampling method. The respondents were provided with a survey form with several sub-items that required parental responses. The home address, distance to school, and mode of transport used by children were some of the information required in the questionnaire. We also asked respondents to provide reasons for their decision in choosing the mode of transportation, as factors that influence their mode selection. Respondents were also asked to assess the pedestrian facilities, security level, and surrounding traffic along the way to school, to compare the level of satisfaction towards public facilities and the vehicle mode selection. The results from the questionnaire survey were analysed to check the distance from the respondents' house to school, with the proposed buffer zone. The buffering tool was used to create a buffer for the neighbourhood area accordingly in finding out the school's coverage area. This process was performed to see the distribution of neighbourhoods within the buffer area to identify whether the distance between the neighbourhood and the school is within walking and cyclable distance.

\subsection{Results and Discussion}

\subsection{The Relationship between Traveling Distance and School Location and Its Influence on Parental Mode Choice}

Fig. 1 shows the zoning location of neighbourhood areas in Section 7, Shah Alam. Each zoning area represents a different location of a neighbourhood area. Section 7 was divided into 5 zoning area to facilitate the location analysis process. As we can see in Fig. 1, the division of zones has been made according to the road name of the neighbourhood area. Two types of respondents participated in the survey which are Section 7 residents and Section 7 nonresidents (of which their children go to Section 7 Primary School).

According to Planning Guidelines for Educational Facilities (2012), the standard distance between the neighbourhood area and primary school is less than $800 \mathrm{~m}$. Based on Table 1 below, the majority of the respondents who live in Zone 1 and 2 travel less $800 \mathrm{~m}$ to the school. Whereas the majority of the respondents who live in Zone 3, 4, 5 and section 7 nonresidents travel more than $800 \mathrm{~m}$ to the school.

Zone 1 is known as Jalan Kristal. There are two types of neighbourhood areas involved which are Jalan Kristal neighbourhood and Kristal Height Condominium. Based on the buffer analysis for neighbourhood area, the travel distance is between a minimum of $400 \mathrm{~m}$ and a maximum of $800 \mathrm{~m}$. Therefore, the distance from Zone 1 neighbourhood area to Section 7 Primary school is within walking distance and is also considered as cyclable distance.

Zone 2 is known as Jalan Plumbum. There are three types of neighbourhood areas which are PKNS flat, Nilam Sari Apartment and Jalan Plumbum Guarded Gated neighbourhood. Based on the buffer analysis, the travel distance is between a minimum of $400 \mathrm{~m}$ and a maximum of $800 \mathrm{~m}$. Similar to Zone 1, the distance from Zone 2 neighbourhood area to Section 7 Primary school is also within walking distance and is also considered as cyclable distance.

Zone 3 consists of Jalan Pualam neighbourhood area. Based on the buffer analysis, the travel distance of the Zone 3 neighbourhood area exceeded the standard guideline of school travel distance. As such, the distance from Zone 3 neighbourhood area to Section 7 Primary school is not within walking distance but is considered as cyclable distance.

Zone 4 consists of Jalan Krisobevil, Jalan Turmalin and Jalan Jasper. Based on the buffer analysis, the travel distance of the Zone 4 neighbourhood area also exceeded the standard guideline of school travel distance. The distance from Zone 4 neighbourhood area to Section 7 Primary school is not within walking distance and neither it's a cyclable distance.

Zone 5 consists of Jalan Platinum neighbourhood area and Danaumas Apartment. Based on the buffer analysis, the travel distance of the Zone 5 neighbourhood area also exceeded the standard guideline of school travel distance. Similar to Zone 4, the distance from Zone 5 neighbourhood area to Section 7 Primary school is not within walking distance nor it's a cyclable distance. 




Fig. 1. School location and neighbourhood zones in Section 7, Shah Alam

Table 1. The relationship between mode of transport and travel time to school

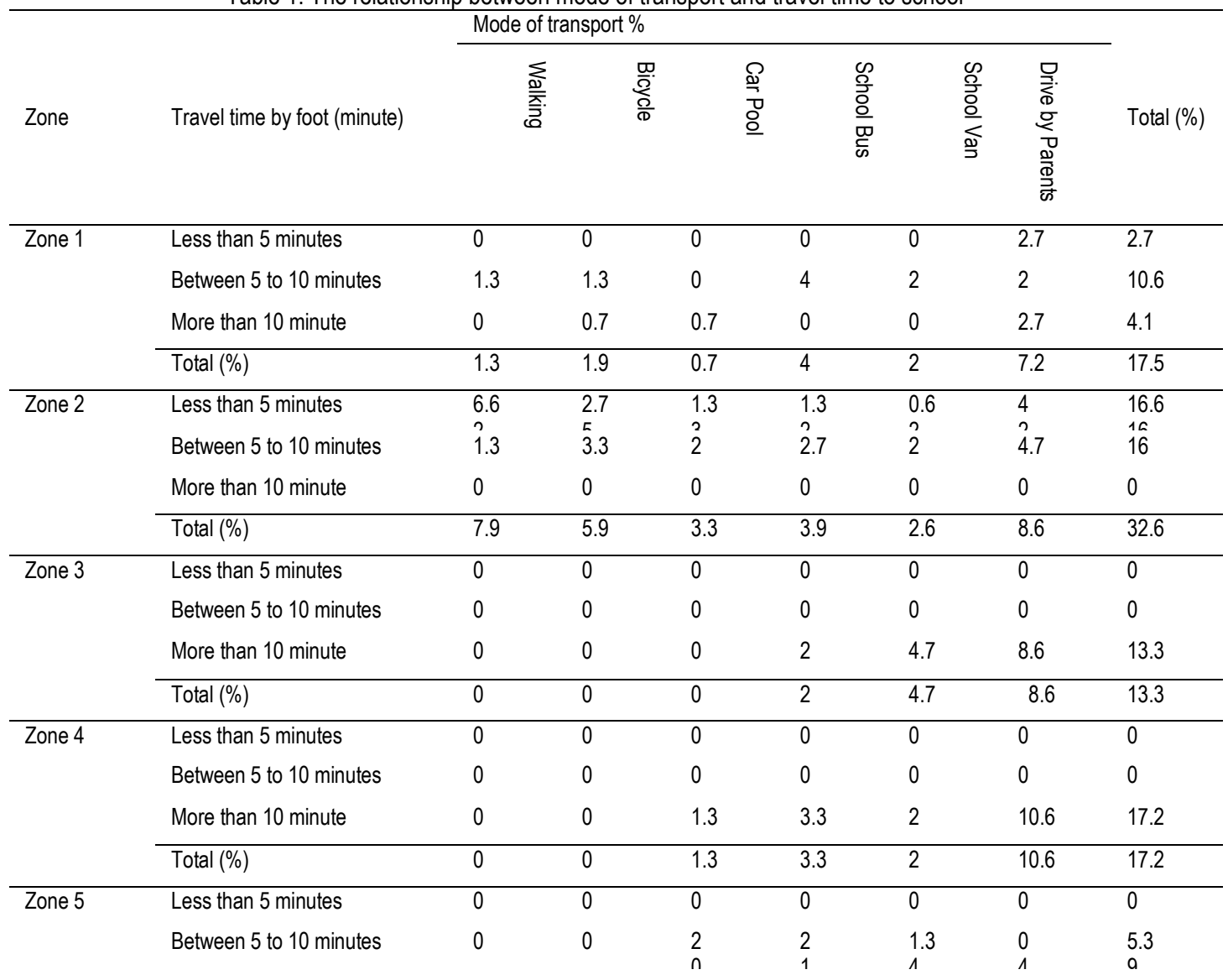






Table 1 shows the relationship between the mode of transport and travel time to school in Section 7. Based on the travel time at Zone 1, the distance from the neighborhood area to the school takes between 10 to 15 minutes, depending upon the types of vehicle used. At Zone 1, motorized transportation is frequently used by the respondents with highest type of transportation mode is the parents' private vehicles.

At Zone 2, the highest type of transportation mode is also the parents' private vehicles, but walking and cycling also is among the favorite mode choice selected by respondents. This is due to the placements of the school which is within the neighborhood area and this minimizes the travel distance to the school. In Zone 2, the travel distance from the Jalan Plumbum neighborhood to school area takes less than 5 minutes.

For Zone 3, Zone 4 and Zone 5, majority of the respondents takes more than 10 minutes to send their children to school. Most of the respondents are using their private vehicles with $8.6 \%$ at Zone 3 , and $10.6 \%$ at Zone 4 . Besides, in Zone 5 , most of the respondents prefer to use school buses with the highest percentage of $5.3 \%$.

Finally, the majority of the Section 7 nonresidents prefer to use their private vehicle to send their children to school. This is because the school is located near to parents' workplace and its easier for parents to send and fetch their children. Based on travel time, Section 7 nonresident respondents took more than 10 minutes travelling time to school.

\subsection{Factors Influencing School Mode Choice}

Based on Table 2 below, the percentage of motor vehicle usage is higher compared to a non-motorized mode such as walking and cycling. Approximately, $43 \%$ of parents chose to send their children to school and $32 \%$ of them did it due to the safety factor. Besides parents' private vehicles, $18 \%$ and $14.7 \%$ of the respondents chose the school bus and school van as a transportation mode and respondents stated that this selection was due to a reasonable monthly fee being charged by the bus and van operators. However, few respondents allow their children to walk and cycle to school and these respondents stated the reason for that is due to the distance. There were only $7.3 \%$ of respondents who prefer their children carpooled to school and these respondents stated the reason for that is due to convenience and quickness reason.

Table 2. Relationship between students' mode of transport and parents' reason for choosing the mode

\begin{tabular}{|c|c|c|c|c|c|c|c|}
\hline \multirow[b]{2}{*}{ Factor choosing a mode of transport } & \multicolumn{6}{|c|}{ Student mode of transport } & \multirow{2}{*}{$\begin{array}{l}\text { Total } \\
\text { - \% } \\
\text { \% }\end{array}$} \\
\hline & 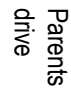 & 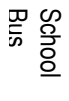 & 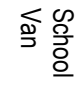 & $\frac{\sum}{\underline{\underline{3}}}$ & 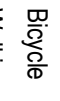 & @্ & \\
\hline \multirow[b]{2}{*}{ Children safety is guaranteed } & $27.3 \%$ & $2 \%$ & $2 \%$ & 0 & 0 & $0.7 \%$ & $32 \%$ \\
\hline & 41 & 3 & 3 & 0 & 0 & 1 & 48 \\
\hline \multirow{2}{*}{ School location close to home } & 0 & 0 & 0 & $9.4 \%$ & $68 \%$ & 0 & $17.4 \%$ \\
\hline & 0 & 0 & 0 & 14 & 12 & 0 & 27 \\
\hline \multirow{2}{*}{ School location far from home } & $6.7 \%$ & $4.7 \%$ & $4 \%$ & 0 & 0 & $2.6 \%$ & $18 \%$ \\
\hline & 10 & 7 & 6 & 0 & 0 & 4 & 26 \\
\hline \multirow{2}{*}{ Convenience and quickness } & $5.3 \%$ & $4.7 \%$ & $4 \%$ & 0 & 0 & $2.7 \%$ & $16.7 \%$ \\
\hline & 8 & 7 & 6 & 0 & 0 & 4 & 25 \\
\hline \multirow{2}{*}{ Reasonable school bus/van fees } & 0 & $6.6 \%$ & $4.7 \%$ & 0 & 0 & 0 & $11.3 \%$ \\
\hline & 0 & 10 & 7 & 0 & 0 & 0 & 17 \\
\hline \multirow{2}{*}{ Parents fear about carelessness issues among bus/van driver } & $3.3 \%$ & 0 & 0 & 0 & 0 & $1.3 \%$ & $4.6 \%$ \\
\hline & & 0 & 0 & 0 & 0 & 2 & 7 \\
\hline \multirow{2}{*}{ Total } & $42.6 \%$ & $18 \%$ & $14.7 \%$ & $9.4 \%$ & $68 \%$ & $7.3 \%$ & $100 \%$ \\
\hline & 64 & 27 & 22 & 14 & 12 & 11 & 150 \\
\hline
\end{tabular}


In this study, parents were also asked about the elements they would consider before allowing their children to walk or cycle to school. The majority of the respondents stated that the safety of the surroundings was the main factor. Based on Table 3, out of 325 responses, $29.8 \%$ has chosen the safety aspect of the surrounding area as the most important factor to allow their children to walk or cycle to school. The physical design of pedestrian walkways/ bicycle track was also another important factor selected by parents $(28.9 \%)$. Also, a distance of less than one mile and the parent's preference of having their friends or relatives accompany their children to school were the other factors mentioned by the respondents. This clearly shows that parents consider safety as their highest priority. Safety is the major factor that affects the type of transportation mode selection by parents whereby parents worry about both the traffic safety and the abduction or "stranger danger" (Dellinger, 2002); (McMillan, 2005); (McMillan, 2003); (Nasrudin, N., \& Md. Nor, A. R., 2013). Negative perceptions towards safety have become obstacles in encouraging children to walk or cycle to school. This negative perception should be eradicated. Therefore, several studies on children's perceptions of transportation modes should be actively conducted.

Table 3. Parents consideration factors in allowing children to walk and cycle to school

\begin{tabular}{lll}
\hline Parents consideration factor & Responses $(\mathrm{N})$ & Percentage $(\%)$ \\
\hline The safety aspect of the surrounding area & 97 & 29.8 \\
The physical design of pedestrian walkways/ bicycle track & 94 & 28.9 \\
Walking distance less than 1 km & 67 & 20.6 \\
Travelling to school accompanied by a friend or sibling & 67 & 20.6 \\
\hline Total & 325 & 100 \\
\hline
\end{tabular}

\subsection{Conclusion}

This study shows there is an insignificant relationship between school location and parent's transportation mode choice as the most common mode of transport has been chosen to school were vehicles driven by parents. Percentage of respondents who chose motor vehicle is higher compared to those who chose the non-motorized mode such as walking and cycling even though the distance from home to school is less than 800 meters. The study found that the majority of the parents who used private vehicles to send their children to school were primarily influenced by the level of safety (crime and traffic). Parents also chose to use personal vehicles to send their children to school because of the convenience and quickness. The results of this study gave the true picture of the urban lifestyle in terms of school transportation. Besides, parental views and concerns about safety showed the need for the improvement of public security, which was the main factor that encourages parents to let their children walk or cycle to school. Security problems caused parents to be less interested in the campaign for active travel transportation. Therefore, safety issues must be resolved first and efforts to improve the physical design of pedestrian walkways and bicycle track should be implemented to support the relationship between planning and physical activity. This can positively influence the development of a healthier society, especially among school children. This study proved that integrated urban development planning in terms of efficiency and safety was one of the factors that will encourage non-motorized travel.

\section{Acknowledgements}

The authors would like to thank the Ministry of Higher Education, Malaysia for funding this research through the FRGS grant 600IRMI/FRGS 5/3 (46/2016) and Universiti Teknologi MARA (UiTM) for supporting the research.

\section{References}

Braza, M. S., Schoemaker, W. \& Seeley, A. (2004). Neighborhood Design And Rates Of Walking And Biking To Elementary School In 34 California Communities American Journal of Health Promotion, 19(2), 128-136.

Bricker, S.K., Kanny, D., Mellinger-Birdsong, A., Powell, K.E. (2002). School Transportation Modes-Georgia, 2000. Morbidity and Mortality Weekly Report 51 (32), $704-$ 705.

Dellinger, A. M. (2002). Barriers to children walking and biking to school - United States, 1999. JAMA: Journal of the American Medical Association, 288(11), 1343.

Hubsmith, D. A. (2006). Safe Routes to School in the United States Children, Youth and Environments, 16(1), 169-190.

Hubsmith, D. A. (2007). Safe Routes to School: 2007 State of the States Report: Safe Routes to School National Partnership.

Martin S, Carlson S. (2005). Barriers To Children Walking to or From School—United States, 2004. JAMA 294(17):2160-2162.

McMillan, T. E. (2003). Walking and Urban Form: Modeling and Testing Parental Decisions about Children's Travel. University of California, Irvine. 
McMillan, T. E. (2005). Urban Form And A Child's Trip To School: The Current Literature And A Framework For Future Research. Journal of Planning Literature, 19(4), 440-456.

Mohamed N., Voon . S., Hashim H., Othman I., (2011). An Overview of Road Traffic Injuries Among Children in Malaysia and Its Implication on Road Traffic Injury Prevention Strategy, MIROS Research Report 03/2011.

Nasrudin, N., \& Md. Nor, A. R. (2013). Travelling to School: Transportation Selection by Parents and Awareness towards Sustainable Transportation. Environmental Science, $1-9$

PBIC. (2007), Safe Routes to School Guide, University of North Carolina Highway Safety Research Center, Safe Routes to School Online Guide Development Committees.

NHTSA. (2004). Safe Routes To School: Practice And Promise: United States Department of Transportation.

Planning Guidelines for Educational Facilities (2012). Garis Panduan Umum dan Khusus Kemudahan Masyarakat. Kuala Lumpur: Jabatan Perancang Bandar dan Desa Semenajung Malaysia.

Pooley, C.G., Turnbull, J., Adams, M.,2005. The Journey To School In Britain Since The 1940s:Continuity And Change. Area 37, 43-53.

Weigand, L. (2008). The Effectiveness of Safe Routes to School and Other Programs to Promote Active Transportation to School. Portland State University. 